\title{
Expertise in Political Contexts: Latour Avec the Third Wave in Science and Technology Studies
}

\author{
David S. Caudill ${ }^{1}$ \\ Villanova University, United States
}

\begin{abstract}
The interdiscipline of science and technology studies ('STS') has been characterized by its descriptive analyses of the presumptions and practices of scientific communities, and by numerous theoretical internal debates over the proper framework of analysis of science. While STS has not been characterized by a powerful effect on law and government, both of which are consumers of scientific expertise, an opportunity arises for engagement in public policy disputes due to the willful ignorance regarding science in the Trump administration, and the negative effects of political agendas and conflicts of interest therein. The urgent need for reliable expertise in such political contexts is addressed in the so-called third wave of STS that is based on Harry Collins and Rob Evans's innovative 'architecture of expertise.' Two recent book chapters, namely Darrin Durant's essay on ignoring experts and Martin Weinel's essay on counterfeit scientific controversies, serve as practical examples of third-wave theory. Bruno Latour, who was engaged in a debate with Collins (and others in STS) concerning their respective approaches during the 1990s, also recently addressed the need for expertise (particularly climate expertise) in government contexts. Nowadays, Collins and Latour both promote consensus expertise and identify its reliance (for its authority) on science as a trusted institution. This article compares the similarities (and acknowledges the differences) between Collins and Latour with respect to their pragmatic strategies, and concludes that notwithstanding internal debates, STS scholars should join Collins (with Evans) and Latour to look outward toward critique and correction of governments that ignore scientific expertise.
\end{abstract}

Keywords: Expertise; sociology of science; public policy; climate change.

\section{Part I. Introduction}

In spite of the huge enrichment of our critical understanding of the nature of science that has taken place since the 1970s, it is still important and intellectually possible to value expertise. . . It is better to give more weight to the opinions of those who, literally, know what they are talking about. ${ }^{2}$

Whether or not a statement is believed depends far less on its veracity than on the conditions of its "construction"- that is, who is making it, to whom it's being addressed and from which institutions it emerges and is made visible. ${ }^{3}$

Those two aphorisms capture important, contemporary aspects of the interdiscipline known as science and technology studies ('STS'). The first, by Harry Collins and Rob Evans, evidences an attempted turn in STS — what they call a 'third wave,' although everyone in STS is not supportive-away from incessant criticism of scientism (by revealing science as a 'social construction') to positing the conditions of relatively reliable expertise. The second, paraphrasing Bruno Latour, seems to push back (by re-emphasizing some 'social' aspects of scientific knowledge), except that Collins and Evans share the view that

\footnotetext{
${ }^{1}$ Professor and Arthur M. Goldberg Family Chair in Law, Villanova Charles Widger School of Law. The author would like to thank Brian W. Blomain, J. D. Candidate, 2020, Villanova University, for his research assistance.

${ }^{2}$ Collins, Why Democracies Need Science, 4.

${ }^{3}$ Kofman, "Bruno Latour, the Post-Truth Philosopher" (an interview with Latour).
} 
science needs to be recognized as a trusted institution; the two aphorisms address two distinct phenomena-expertise, and its reception as expertise.

STS has been characterized for decades by its descriptive analyses of the presumptions and practices of scientific communities, and by numerous internal, theoretical debates over the proper framework (and units) of analysis. While a lively discourse exists concerning the importance of making a difference in the world through practical engagements by STS scholars, STS has not, in my view, been characterized by a powerful influence on law and government. That failure is due, in part, to the perennial emphasis in STS on disclosing and discussing, for example, the social, cultural, ethical, rhetorical, and economic aspects of scientific research and writing. The scientific establishment, to the extent scientists are aware of STS, generally react negatively to what appears to be challenges to scientific authority, the goal of objectivity, and the primacy of Nature in determining the results of scientific research. Moreover, in legal (both in regulatory settings and in the courtroom) and political contexts in which scientific expertise is frequently relied upon, the last thing judges, legislators, and administrators want is a litany of social determinants (or co-determinants) of scientific knowledge. However, over the last several years, the situation has changed. The Trump administration is striking in its disrespect for consensus science, and some STS scholars have begun to emphasize the urgent need for government to rely on consensus science.

The Trump administration's multifaceted attack on science - through lies, interference with research, spending cuts, disruption of conventional scientific processes, ignorance, active hostility, and the politicization of science-calls out for an effective response, and for critique and correction on the part of STS scholars. And yet, how precisely do we respond to a political regime opposed to allowing a role for consensus scientific knowledge in policy deliberation? Do we take a detached, descriptive stance, or a more engaged response aimed at identifying effective corrections?

The purpose of this article is to reflect on the possibilities for critique and correction of a government that ignores expertise for political reasons. In Part II, I briefly survey examples of how the current United States (US) administration alternatively tosses aside, misrepresents, denies, defunds, ignores, characterizes as political, and attempts to disprove consensus science. In Part III, I analyze the potential relationships between science and politics developed by Harry Collins and Rob Evans in their work on expertise, which is the basis for the so-called 'third wave' of STS. As to technical decision-making in the public domain, Collins and Evans have argued for a strong distinction between political rights and expertise, in part to avoid hidden political agendas in public controversies. Part IV offers two brief examples of compelling, practical critiques of science infected by politics, respectively focused on events in Australia and South Africa; both studies were inspired by the 'third wave' analytical framework. In Part V, I recall the 1992 debate between Collins (with Yearley) and Latour (with Callon), during which Latour was criticized for the 'realist' turn in his actor network theory_Latour's own attempt to move beyond the second wave of STS. Conversely, Collins was accused of perpetuating the nature/society divide (by explaining the closure of a scientific controversy in terms of Society, not Nature). Nowadays, it is Collins who, by initiating the third wave in STS, is accused of a certain realism, while Latour's recent Down to Earth (2018), concerned with the need for governments to attend to climate science, clearly emphasizes the cultural and institutional support upon which expertise relies. Without implying that Collins (with Evans) and Latour are the only STS scholars concerned with expertise in the public policy realm, it is significant that three of the major scholars associated with STS - the two initiators of the third wave and an originator of actor network theory - have converged on a constructive, pragmatic tangent (the shared motivation to limit political influences on science) notwithstanding their ongoing disagreements (which I characterize as internal to STS). I conclude in Part VI that STS scholars nowadays should, using their own expertise in expertise, join Collins (with Evans) and Latour to look outward - setting aside theoretical differences for a moment - toward critique and correction of governments that so strikingly ignore scientific expertise, in part to combat distrust of scientific institutions.

\section{Part II. Science and Expertise in the Trump Administration}

\section{Before the Election}

If the Trump administration were to pollute the scientific inquiry at the USDA [United States Department of Agriculture] with politics, research grants will go ... to [his] closest allies. . . . Junk science will be used to muddy issues. ... The science will suddenly be 'unclear.' There will no longer be truth and falsehood. There will just be stories, with two sides to them. ${ }^{4}$

Of all the books written about the organization (or disorganization) of the Trump administration, Michael Lewis's The Fifth Risk is the most relevant with respect to the appropriation of science and scientific expertise by the US government. Lewis begins his book with a vignette about the need for favored first-time presidential candidates to prepare for a transition to power

\footnotetext{
${ }^{4}$ Lewis, Fifth Risk, 114, discussing the concerns of Cathie Wotecki (chief scientist at the Department of Agriculture- the "USDA"- under President Obama) about her replacement at the USDA.
} 
once elected. Former New Jersey Governor Chris Christie volunteered to head the transition team, but soon discovered that Trump 'thought the planning and forethought pointless. ${ }^{5}$ Christie and his team were fired, and Trump decided to handle the transition himself. ${ }^{6}$ The remainder of The Fifth Risk is a catalog of examples of how unqualified Trump was to make cabinet and other senior appointments, especially those related to science and scientific research. We now observe that Trump 'is no fan of research, and his administration has no overarching strategy for funding science. ${ }^{7}$

Lewis argued that the Trump administration is characterized by 'willful ignorance' - an impulse or desire not to know. ${ }^{8}$ For example, Trump's first budget 'eliminated all [Dept. of Energy] research on climate change,' and cut in half funding for sciencebased 'work to secure the electrical grid from attack or natural disaster.' Lewis concluded that if 'you are seeking to preserve a certain worldview, it actually helps to gut the science.' 9

\section{A Few Years After the Election}

I have a natural instinct for science, and [as to climate change,] I will say that you have scientists on both sides of the issue. ${ }^{10}$

There are numerous ways that science and scientific consensus are challenged in the Trump administration. First, there are lies. As to environmental issues, 200 of Trump's '9,179 false statements' (as of March 17, 2019) concerned the environment; for example, Trump claimed that the US tops all environmental lists - not true, and yet calling this a lie 'may well be inaccurate ... The president ... may actually believe' it. $^{11}$

Second, there is interference with research, as in the case of the US Department of Health and Human Services decision to ban the study of human fetal tissue on the part of scientists at the National Institutes of Health. ${ }^{12}$ The Union of Concerned Scientists discerned a virtual:

war on science - undermining the role of science in public policy, giving industry undue influence on [decision-making] processes, creating a hostile environment for federal scientists, and reducing public access to scientific information. ${ }^{13}$

This political interference includes (i) weakening federal advisory committees, (ii) leaving high-level science positions vacant, or appointing 'conflicted individuals to scientific leadership positions,' some with 'little science background and with strong ties to the industries they are charged with regulating,' (iii) signing 'resolutions rolling back science-based protections, including safe drinking water standards,' and (iv) removing 'climate-related content from several government communications. ${ }^{, 14}$

Third, there are the spending cuts; for example, in the 2018 budget proposed by Trump, there were not only reductions in medical and scientific research, but also 'a \$129-million cut to the enforcement of programs that support clean air and water.' 15

\footnotetext{
${ }^{5}$ Lewis, Fifth Risk, 22.

${ }^{6}$ Lewis, Fifth Risk, 31-32.

${ }^{7}$ See Mervis, "Trump's 2018 Budget Proposal 'Devalues' Science.”

${ }^{8}$ Lewis, Fifth Risk, 77, "Ignorance allows people to disregard the consequences of their actions." Lewis, Fifth Risk, 115.

${ }^{9}$ Lewis, Fifth Risk, 80.

${ }^{10}$ Farber, "Trump on the Environment," quoting President Donald Trump.

${ }^{11}$ Farber, "Trump on the Environment." Switzerland tops the list, the US is \#27.

${ }^{12}$ See Grens, "NIH Scientists Banned."

An anonymous senior official in President Donald Trump's administration tells the Associated Press that the decision was Trump's ... "Prohibiting valuable research that uses fetal tissue that is otherwise going to be discarded doesn't make any sense," Lawrence Goldstein, a regenerative medicine specialist at the University of California, San Diego, tells the AP. "It blocks important future research vital to the development of new therapies."
}

Grens, "NIH Scientists Banned."

${ }^{13}$ Union of Concerned Scientists, "Sidelining Science Since Day One."

${ }^{14}$ Union of Concerned Scientists, "Sidelining Science Since Day One." "For example, the administration's nominee for chief scientist at the US Department of Agriculture [in 2017 had] no significant scientific credentials and has expressed views on climate change and sexuality that are at odds with scientific consensus." Sharfstein, "Science and the Trump Administration."

${ }^{15}$ See Collier, "Massive cuts to Science and Medicine." In the end, Trump did not get all the cuts he wanted, but he did manage to reduce funding to the Environmental Protection Agency by 31 percent, and the funding to the Department of Agriculture by 21 percent.

"Percentage Change in the Proposed 2018 Federal Budget of the United States from 2017 Edition, by Department or Service," available at https://www.statista.com/statistics/687901/budget-2018-proposal-change-in-budget-by-department/. 
Fourth, there appears to be a pattern of disrupting our 'usual scientific processes,' because development and expression of genuine 'scientific evidence or insight might threaten achievement of major ideological or political objectives.' ${ }^{16}$ For example, a study on the health effects of mountaintop-removal coal mining was halted, while the Environmental Protection Agency administrator 'asserted the fringe view that that carbon dioxide is not a primary contributor to global warming.' ${ }^{17}$ Such pseudoscience can become 'a cultural force' adding to the mistrust of scientific institutions — pseudoscientists:

argue that ... scientific consensus emerges from a conspiracy to suppress dissenting views. They produce fake experts [with] views contrary to established knowledge but [with no] credible scientific track record. They cherry-pick the ... papers that challenge the dominant view as a means of discrediting an entire field. ... And they set impossible expectations of research. ${ }^{18}$

In short, pseudoscience has the 'form' of science without the substance. ${ }^{19}$

A fifth way that science is under attack is the seeming ignorance of President Trump with respect to scientific matters; during his campaign, Trump's notions that global warming is a 'total' hoax, 'created by and for the Chinese,' and that it is based on 'faulty science and manipulated data,' showed 'a disregard for science that is alarming., ${ }^{20}$ Sixth, the Trump administration has moved beyond a 'largely apathetic' approach to science to one that is 'actively hostile,' reflected in its unwillingness to 'take the threat of human-caused climate change seriously. ${ }^{21}$ Proposals 'to open more federal lands to drilling and mining' and to 'deregulate pollution monitoring' signal hostility, ${ }^{22}$ and there have been attempts to suppress information on climate change:

White House officials barred a State Department intelligence staffer from submitting written testimony ... to the House Intelligence Committee warning that human-caused climate change could be 'possibly catastrophic' [and referencing] the scientific consensus on climate change. ${ }^{23}$

Hostility is also reflected in the administration's 'plans to form an internal group ... with the task of refuting the clear scientific consensus about the growing threat climate change poses. ${ }^{24}$ Fifteen senators reacted to this plan:

Allowing a fossil fuel industry-funded climate change denier and other climate skeptics to conduct an 'adversarial peer review' of recent climate science will create an environment of inaction that needlessly threatens our national security. ${ }^{25}$

This is how mistrust of scientific institutions looks - 'arrogance and disrespect for scientific advancement [and a] very demoralizing lack of respect for your own experts and agencies. ${ }^{26}$

Finally, a seventh way that science is attacked in the Trump administration is by turning science into politics, into matters of perspective - as if there are two legitimate sides to every controversy and, therefore, no consensus concerning, for example, climate science. ${ }^{27}$ The right-wing radio personality Rush Limbaugh, to whom Trump gave the Presidential Medal of Freedom on February 4, 2020, made this style of distortion an explicit part of his support for the Trump administration. For example, when Limbaugh read (in the New York Times) about instances of fraud (including fabrication of data and inability to replicate findings) in psychological research, he opined:

I don't think it's limited to psychology. ... I think everything's been so corrupted, science especially, by politics. ...The vast majority of what you hear [from journals like Science] is just bogus and totally made up ... Folks, from nutrition to psychology

\footnotetext{
${ }^{16}$ See Sharfstein, "Science and the Trump Administration."

${ }^{17}$ Sharfstein, "Science and the Trump Administration."

${ }^{18}$ Sharfstein, "Science and the Trump Administration," quoting Atul Gawande's graduation address at the California Institute of Technology in 2016.

${ }^{19}$ Sharfstein, "Science and the Trump Administration" (emphasis added).

20 “Trump's Views on Science Are Shockingly Ignorant," editorial. As to Trump's denial of scientific facts, see Andrews, "Here's a List of All the Science."

${ }^{21}$ See Lewis, "Year of Trump."

${ }^{22}$ Lewis, "Year of Trump."

${ }^{23}$ Eilperin, "White House Blocked Intelligence."

According to several senior administration officials, all of whom spoke on the condition of anonymity in order to talk about internal deliberations, Trump officials sought to cut several pages of the document on the grounds that its description of climate science did not mesh with the administration's official stance.

Eilperin, "White House Blocked Intelligence."

${ }^{24}$ Van Hollen, "Van Hollen, Senators Call on Trump," quoting letter from senators to President Trump.

${ }^{25}$ Van Hollen, "Van Hollen, Senators Call on Trump."

${ }^{26}$ Pierce, "Trump Administration Will Stop at Nothing," quoting Johan Rockström, the director of the Potsdam Institute for Climate Impact Research in Germany.

${ }^{27}$ Holmes, "There Aren’t Two Sides to Science."
} 
to climate change to global warming to fracking, what has been exposed here is that science is no different than anything else in politics. It is totally determined by money. ${ }^{28}$

This alleged corruption is for Limbaugh 'why something like Trump happens,' insofar as 'so many people in the country have lost faith in so many institutions they used to trust. ${ }^{29}$ People know, Limbaugh argued, 'that there is a private, powerful elite group of people [who] have such total control over things they're able to rig the results. ${ }^{30}$ This becomes a narrative about dangerous, elitist technocrats who pretend to be experts, but are fraudsters, and a citizenry who want to take back control:

The people of this country know ... who the people are in charge of the levers benefiting ... themselves. ... So it all makes sense. So much of it's fake. Being lied to left and right in order to secure our support for something that's fraudulent. ${ }^{31}$

In the early months of 2020, as the coronavirus swept through the US, Trump's 'distaste for relying on scientific expertise' was on full display in daily White House briefings. ${ }^{32}$ While citizens had perhaps grown used to Trump's past misrepresentations as to scientific matters, misinformation 'during a pandemic [carries] a unique danger because [it] may sow distrust in public health officials.' $^{33}$

In the next section, I consider a recent effort both to carefully define expertise and, in public policy settings, to disting uish it from politics.

\section{Part III. Science and Politics}

Where science is ambiguous, politics begins. ${ }^{34}$

Unfortunately, the foregoing aphorism is not exactly true-politics can infect, and negatively affect, the public uptake of even the best consensus science. The relationship between science and politics is an important focus in recent studies of expertise, often referred to as the 'third wave' in STS, by Cardiff sociologists of science Harry Collins and Rob Evans. ${ }^{35}$ Briefly, the term 'third wave' identifies a proposed addition, or complement, to the dominant methodological approach - the 'second wave'in STS. The term 'first wave' identified an initial, idealized view of science among sociologists of science, namely, the earlyto mid-twentieth century belief that 'science was unquestionably the pre-eminent form of knowledge-making and that its knowledge was absolute and universalistic'; this gave way to a 'second wave' of STS scholars who viewed science and its findings as heavily influenced, even determined in part, by their social context - 'scientific truth is best seen as an outcome of negotiation and agreement located within social groups. ${ }^{36}$ Good science needed no social explanations in the 'first wave' (or in the minds of most practicing scientists nowadays), although errors could be explained by bias or interests; but in the 'second wave,' any strong distinction between science and society breaks down. Harry Collins has been a leading force in the second wave of STS, but in recent years he started to balk at one of its:

important implications for ... the use of scientific advice in policy-making. [The 'second wave'] provided a powerful argument against technocracy by showing how expert advice rested on a sea of social assumptions. This, in turn, led to arguments in favour of the democratization of science, and of expertise more generally. ${ }^{37}$

The rejection of that second-wave notion of democratization - of the idea that the concerns of the citizenry should be reflected in science-is the genesis of the Collins and Evans proposal for a 'third wave.' STS scholars should, they argued, study the 'architecture' of expertise and experience, and, in the process, limit the extension of technical decision-making rights to socalled 'lay experts,' an oxymoron in the context of public policy. (Collins and Evans started that process by developing a taxonomy of numerous types of expertise.) In Collins and Evans's terminology, core sets of scientists are the arbiters of technical achievement, and the mantle of expertise should belong only to those with specialist knowledge (gained through education and training or from experience in the relevant field) and not to ordinary citizens (who can certainly gather data, or

\footnotetext{
${ }^{28}$ Limbaugh, "Peer Review Science Exposed as Fraud."

${ }^{29}$ Limbaugh, "Peer Review Science Exposed as Fraud."

${ }^{30}$ Limbaugh, "Peer Review Science Exposed as Fraud."

${ }^{31}$ Limbaugh, "Peer Review Science Exposed as Fraud."

32 Alba, "Medical Expert Who Corrects Trump," A11, paraphrasing comments by Professor Whitney Phillips.

33 Alba, "Medical Expert Who Corrects Trump," A11, paraphrasing comments by Professor Whitney Phillips.

${ }^{34}$ Gopnik, "Younger Longer," 37, quoting Joseph Coughlin, the founder and director of MIT's AgeLab.

${ }^{35}$ Collins, Why Democracies Need Science, 16-18 (discussing the technical and the political phases of decision-making in policy contexts).

${ }^{36}$ Collins, Why Democracies Need Science, 9-10.

${ }^{37}$ Collins, Why Democracies Need Science, 10.
} 
participate 'in existing democratic institutions without pretending to be, or being described as, experts'). ${ }^{38}$ The 'third wave' is not, despite accusations otherwise, intended to be a complete break from the careful identification of the social aspects of science exemplified in 'second-wave' methodology, but is intended as a corrective to 'preserve the idea of expertise as specialist knowledge [in] the trade-offs between expert authority and democratic accountability. ${ }^{39}$

In their effort to capture the elements of policy disputes involving scientific expertise, Collins and Evans distinguished between 'two different institutional practices' - a 'technical phase' and a 'political phase' in the decision-making process:

It was important to retain the distinction between them if science, already seen by some as 'politics by other means,' was not to become indistinguishable from the networking, horse-trading and pork-barreling that characterizes the overtly political elements of the public domain. ${ }^{40}$

Policy decisions on the basis of expertise involve both advice and decision, each of which requires a unique analytical approach. ${ }^{41}$ In the technical phase, expert advice is solicited both from formally trained scientists or experience-based experts (called contributory experts insofar as they can contribute to the relevant field), and from relevant interactional experts (perhaps non-scientists, or scientists from another field) insofar as they know the language of a domain and can interact with core scientists. Moreover, the technical phase is characterized (normatively) as allowing only intrinsic politics (internal to scientific research) and not extrinsic politics, 'to minimize the effect of political bias and influence.' ${ }^{42}$

\begin{abstract}
This means that technical advisors should not exaggerate the certainty or impact of their work in order to influence the political decision, and that decision-makers should not demand that engineers and scientists draw firm conclusions when this cannot be done. ${ }^{43}$
\end{abstract}

The political phase of governmental institutions and processes then follows - a political decision is made taking into account the expert advice. Theoretically and normatively, all citizens in a democracy have an equal stake, and the right to participate, in this decisive phase. ${ }^{44}$

The ultimate goal, as unattainable as 'perfect' democracy or justice, is a science independent of extrinsic political influence. ${ }^{45}$

By way of contrast, compare the cynical view expressed by Rush Limbaugh (in the previous section) - the scientific community is populated by fraudsters, scientific results are corrupted by money, and all science is politics—with Collins and Evans:

Why are there so few cheats and frauds in science? [The values of science] are all—or nearly all—based in a desire to reach the truth of the matter. They are robust because the worldview of the majority of scientists is the old-fashioned worldview that these values not only can, but will, reach the truth of the matter. ${ }^{46}$

In terms of STS, we need 'to preserve the moral imperatives that guided science under' the so-called first wave, even in the face of evidence that scientists do not always act in accordance with the norms associated with Robert Merton (the sociologist of science whose views epitomize the 'first wave' in STS) ${ }^{47}$ One of those norms, disinterestedness, is especially relevant to the issue of politics in science - one's personal beliefs or one's favorite cause should not influence the results of one's scientific research.

\footnotetext{
${ }^{38}$ Collins, Why Democracies Need Science, $8,11,14$. This view is decidedly not a wholesale critique of citizen participation in science.

${ }^{39}$ Collins, Why Democracies Need Science, 11.

${ }^{40}$ Collins, Why Democracies Need Science, 17.

${ }^{41}$ Collins, Why Democracies Need Science, 17.

${ }^{42}$ Collins, Why Democracies Need Science, 17. Regarding contributory and interactional expertise, see Collins, "Third Wave in Science Studies," 251-256.

${ }^{43}$ Collins, Why Democracies Need Science, 77 . Moreover, "political decision-makers should not misrepresent technical advice in order to present political choices as technical necessities." Collins, Why Democracies Need Science, 18.

${ }^{44}$ Collins, Why Democracies Need Science, 18. "Crucially, [therefore,] the political phase always has priority over the technical phase and so there is no question of technocracy." Collins, Why Democracies Need Science, 18.

${ }^{45}$ Collins, Why Democracies Need Science, 17-18, 30.

${ }^{46}$ Collins, Why Democracies Need Science, 37.

${ }^{47}$ Collins, Why Democracies Need Science, 37, see also Collins, Why Democracies Need Science, 47-50. The "Mertonian" norms for science were (i) the idea that all scientific knowledge should be shared among all scientists, (ii) the idea that scientists can contribute irrespective of their race, gender, culture or nationality, (iii) disinterestedness in research, with respect to personal beliefs or a cause one supports, and (iv) skepticism to ensure critical scrutiny of the results of science. Collins found these "just good in themselves in a selfevident kind of way." Collins, Why Democracies Need Science, 48.
} 
The problem with the norm of 'disinterestedness' is that scholars in the second wave of science studies revealed that science is inevitably affected by interests, often in subtle or even invisible ways. Science is not pure-for example, it is part of a culture, it takes part in a language, it has a history, and it is limited by economic and ethical structures, all of which can influence the results of an ideally objective observation and recording of results. Moreover, 'there are many instances of successful science that do not match' Merton's norms. ${ }^{48}$ Collins and Evans, designating their argument - for confirming (and choosing, morally) the ideals of science as self-evident-'elective modernism,' recognized that scientists often fall short of the ideal of disinterestedness:

[Much of the second-wave] contemporary science studies-inspired analysis argues that every scientific conclusion is invested with politics, but elective modernism argues that this does not mean we must aspire to make every scientific act a political act. $^{49}$

If the problem for first wave idealized images of science is the second wave's revelations that science does not always fit the ideal, then the problem for Collins and Evans was somehow to honor and accept both the first and second wave; it is a problem because scholars in the second wave are critical of 'the touching naïveté of natural scientists,' while Collins and Evans argued that 'we are still in need of that simple model of science,' even as they agree with the second-wave critique of idealistic images of science. ${ }^{50}$

Their solution is to distinguish between the aspirations or ideals, on the one hand, and the realities that (i) sometimes the norms are not followed in good science and (ii) sometimes the norms are not efficacious. ${ }^{51}$ Moving beyond Merton's 'formative' norms, Collins and Evans added (to their list of values) honesty and integrity, a preference for experts over non-experts, clarity, individualism (in the sense of being willing to stand against a majority, on the basis of an individual observation), continuity (in the sense of not breaking with valued, existing knowledge), open-endedness (the other side of the 'continuity' coin), generality in application, and valuing expertise. ${ }^{52}$ With those values, the rejection of extrinsic political influences on science, along with the recognition that intrinsic politics in science is inevitable, can now be explained under elective modernism:

\begin{abstract}
Intrinsic politics means that experts try to resolve their differences whilst adhering to the values we have just described. This means disputes are resolved by reference to observation and theory and without resorting to arguments about the consequences or desirability of particular outcomes; to do this would be to make political concerns extrinsic and to stop acting 'scientifically.",53
\end{abstract}

It would be fair for a reader to ask what Collins and Evans mean here by experts' 'differences' or scientific 'disputes' - a dispute among scientists over how much evidence of risk is sufficient before the government should act is neither (i) resolved by observation and theory, nor (ii) independent of political concerns exemplified in arguments over consequences. Therefore, Collins and Evans are likely referring to propositional disagreements about scientific knowledge in which experts are arbiters of consensus, but there is a danger that their terminology ('disputes are resolved by') suggests a much greater role for scientists in politics, which is exactly the concern that Trump and his apologist Limbaugh want to publicize! Scientists do indeed share the 'extrinsic' political sphere with the citizenry, but Collins and Evans were not, as evidenced by their own concerns with technocracies (discussed below), suggesting scientists have more rights there.

For Collins and Evans, it is 'close to self-evident' that when it comes to observable phenomena, 'we should all prefer the views of scientific experts and those who share their values' over other kinds of experts (e.g., highly trained astrologers) as well as non-experts - scientific experts know 'what they are talking about [and] have come to know what they are talking about while following the formative aspirations of science. ${ }^{54}$

When a technical issue arises in the public policy context, the political phase begins - Collins and Evans are at pains to show that elective modernism does not imply a technocracy. ${ }^{55}$ Although technical experts are rarely the decision-makers, they do

\footnotetext{
${ }^{48}$ Collins, Why Democracies Need Science, 48.

${ }^{49}$ Collins, Why Democracies Need Science, 49.

${ }^{50}$ Collins, Why Democracies Need Science, 37.

${ }^{51}$ Collins, Why Democracies Need Science, 44-48. Because Merton "thought that science was the most effective way of gaining knowledge ... he argued that the norms of science should be adhered to because they were efficacious." Collins, Why Democracies Need Science, 44.

${ }^{52}$ Collins, Why Democracies Need Science, 50-54

${ }^{53}$ Collins, Why Democracies Need Science, 60.

${ }^{54}$ Collins, Why Democracies Need Science, 60-61.

${ }^{55}$ Collins, Why Democracies Need Science, 69, in which Collins acknowledged their "scholarly context," namely science studies in which many "second wave" scholars emphasize the importance of democratic decision-making.
} 
advise 'and politicians decide in many democratic societies. ${ }^{56}$ This raises the concern that policy makers are constrained by the experts, insofar as they 'choose from the options the experts provide' -implying a technocracy. ${ }^{57}$ Elective modernism shares this concern, but maintains a place for expertise by avoiding the fact-value distinction that justifies a technocracy:

Instead of attempting to defend scientific and other technical expertise by reproducing the 'fact-value' distinction, elective modernism distinguishes between scientific values and democratic values - a value-value distinction — and defends science on moral not instrumental grounds. ${ }^{58}$

Policy makers need not follow expert advice - therefore, no technocracy is envisioned - but the decision to reject expert advice should be 'done openly,' and the 'technical consensus must never be disguised or distorted so as to make the political decision easier.'

Collins and Evans, therefore, provide an image of (i) how expertise should function in public policy contexts and (ii) how a government like the Trump administration fails to respect expertise-for example, by distorting consensus science to make a political decision easier. Each of the ways in which science is under attack by the Trump administration-lies, interference with research, spending cuts, disruption of conventional scientific processes, ignorance, active hostility, and the politicization of science - are ways of disguising or distorting consensus science. ${ }^{59}$ In that current situation, what can be done? In the next section, I summarize two studies based on and inspired by STS 'third wave' priorities. Each provides a framework for critique and correction of situations like we face in the US today. Following that summation, in the next section on Latour's concerns with politics and expertise, I return to the history of STS, particularly the 1992 debate between Collins and Latour over the appropriate direction of STS with respect to the social construction of science.

\section{Part IV. Strategic Tools of the Critic}

REPORTER: Have you read the alarming UN report about imminent, drastic climate change?

TRUMP: It was given to me, \& I want to look at who drew it. You know, which group drew it, because I can give you reports that are fabulous \& reports that aren't so good. ${ }^{60}$

Two of the ways in which governments like the Trump administration attack consensus science-by ignoring experts, or by claiming that there are two sides to every issue and, therefore, a scientific controversy-are addressed respectively in two studies of expertise outside the US, both of which are influenced by Collins and Evans's analytical framework. The authors of these studies begin with an acknowledgment that numerous genuine scientific controversies persist wherein no settled consensus has emerged - that phenomenon becomes a reason to avoid giving too much authority to scientists, who do not have all the answers, in the democratic process.

\section{Darrin Durant’s Ignoring Experts}

When experts ... are constructed as undemocratic authorities, as dangerous experts, that image is reasonable in mild form but normatively disabling in its more radical version. ${ }^{61}$

Here, Durant focuses on the reasons that scientific experts might be ignored in governmental contexts - their advice is often 'diverse and contradictory,' and their 'input into democratic deliberation and decision-making can also be wrong, unhelpful and capable of misleading about what is at stake.' ${ }^{6}$

\footnotetext{
${ }^{56}$ Collins, Why Democracies Need Science, 69.

${ }^{57}$ Collins, Why Democracies Need Science, 70.

${ }^{58}$ Collins, Why Democracies Need Science, 70 , social scientists need to be involved in deciding what counts as the best science: consensus.

Collins, Why Democracies Need Science, 86.

${ }^{60}$ Rupar, Tweet, quoted in Holmes, "There Aren't Two Sides to Science."

${ }^{61}$ Durant, "Ignoring Experts," 33.

62 Durant, "Ignoring Experts," 34.
}

${ }^{59}$ Collins recognized the difficulty in determining "the current scientific consensus," due to the fact that scientists are not disinterested"they believe in their work and champion it fiercely." Collins, Why Democracies Need Science, 84-85. Moreover, the "substance and strength of consensus . . is a social scientific fact ... not a natural scientific fact." Collins, Why Democracies Need Science, 85. Therefore,

The last fifty years of science studies has been about developing a deep reflective and analytical understanding of the social constitution of science ... That understanding should make a contribution to the definition and recognition of scientific consensus, its nature and strength. Under Wave One there was only scientific truth; now there are grades of 
Conversely, there are two reasons that are less than compelling - the notions that experts are dogmatic (and, therefore, not selfcritical) and dangerous - and there are parallels between the strategies to avoid consensus science in the Trump administration and Durant's example of how expertise is ignored in Australia.

Conceding the risk of allowing experts to control decision-making without political deliberation, Durant first identified the public's concern that experts can be 'robotic' - that is, so prone to dogmatism and authoritarianism that they are not selfreflective: 'experts are depicted as mechanically reproducing their scientific programming. ${ }^{93}$ Durant's example of this phenomenon is the politicization of 'research and discussion in Australia about climate change,' which is 'signaled by the roller-coaster on which climate advisory bodies have ridden, especially since 2010.' ${ }^{64}$ The Labor government established a Climate Commission in 2011 and a Climate Change Authority in 2012, in both cases to provide independent advice, but in 2013, the new Liberal government dismantled the Climate Commission and appointed new members to the Climate Change Authority who support 'climate inaction.' 65

After conducting numerous interviews with scientists, Durant concluded that this concern with dogmatism on the part of scientists is not justified. Nevertheless, the alienating image of the robotic expert has become a barrier to the public reception of otherwise helpful and useful expertise:

Because authority depends on the judgment of those under it and those judgments are conditioned by shared beliefs, values and judgments, to think of experts as robots is to undermine the possibility of anything shared between experts and lay publics. ${ }^{66}$

While limitations on the authority of experts makes sense, the combination of viewing experts as robotic and as dangerous serves to delegitimize independent advisory institutions:

If the legitimacy of expertise as an independent institution is brought into doubt[, the] first casualty is going to be that partisan politics can be set adrift from the [expertise that can] act as a check against ... completely ungrounded policy claims. ${ }^{67}$

Durant illustrates this problematic framework with reference to the electricity blackout in South Australia in September 2016, after power poles, transmission towers, and transmission lines were blown down in a storm:

Australia's (conservative) Liberal-National coalition government swiftly blamed renewable energy for the blackout, with conservative parliamentarians blanketing the media with claims the blackout was due to the State's over-reliance on wind power. ${ }^{68}$

That was demonstrably not true, and 'all those conservative parliamentarians who blamed wind power for the blackout had in fact been advised ... that the problem was not wind power.' ${ }^{69}$ Why did they ignore the experts? Durant concluded that experts were impliedly, and unjustifiably, viewed as threatening, robotic, or dangerous, any of which leads to ignoring them as a relatively independent institution that can guide political decisions.

\section{Martin Weinel's Recognizing Counterfeit Scientific Controversies}

A realistic image of science and scientists would acknowledge that disagreements are common, a point made regularly in STS research, and may become 'even fiercer if the contested issue is of import to science policy-making. ${ }^{70}$ However, there is another type of scientific disagreement that appears not in scientific communities,

but is specifically and deliberately manufactured to create a public perception of prevailing uncertainty and controversy [in science] and to disguise relative certainty and consensus that might exist in expert communities. ${ }^{71}$

\footnotetext{
${ }^{63}$ Durant, "Ignoring Experts," 35.

${ }^{64}$ Durant, "Ignoring Experts," 39.

${ }^{65}$ Durant, "Ignoring Experts," 39.

${ }^{66}$ Durant, "Ignoring Experts," 42.

${ }^{67}$ Durant, "Ignoring Experts," 42, 47.

${ }^{68}$ Durant, "Ignoring Experts," 47-48.

${ }^{69}$ Durant, "Ignoring Experts," 48, citing Hutchens, "Turnbull Ignored Advice" (the Australian Electricity Market Operator gave that advice, blaming the blackout on the storm, voltage settings, and even market dynamics).

${ }^{70}$ Weinel, "Recognizing Counterfeit Scientific Controversies," 54.

${ }^{71}$ Weinel, "Recognizing Counterfeit Scientific Controversies," 54.
} 
In those contexts, it is important for policy makers to be able to 'assess whether [there is genuine] uncertainty in the expert community, or whether the controversy has been artificially created to serve other ends. ${ }^{7}$

For an example of a counterfeit controversy (which should not affect the policy process), Weinel turns to the paralyzing (in terms of governmental decision-making) debate in South Africa over the safety of azidothymidine (AZT), a drug to reduce the risk of mother-to-child HIV transmission during pregnancy and childbirth. The Mbecki government justified delay in providing the drug by 'manufacturing' an 'ongoing scientific controversy.'73

Weinel argued that STS can help identify counterfeit scientific controversies by using a criteria-based approach. Conceding that there are situations in which identifying a manufactured controversy will be 'difficult or impossible,' Weinel nevertheless sought 'practical ways to conduct demarcation work in an explicit manner by identifying possible criteria.' ${ }^{74}$ The criteria he proposed are:

1. Conceptual continuity with science, that is, are the claims 'part of the domain' of science? If not, they cannot cause a controversy. ${ }^{75}$

2. Expertise of the claim-maker? Those "who make claims that challenge a consensus . . . should possess relevant technical expertise. ${ }^{, 76}$

3. Ongoing disagreement within the expert community, not outside audiences? Otherwise, it is not a 'genuine scientific controversy. ${ }^{77}$

4. Constitutive work, that is, is there some kind of scientific evidence? Baseless speculations and unsubstantiated beliefs do not qualify. ${ }^{78}$

Weinel argued that if a single criterion is not met, the controversy is counterfeit - a genuine scientific controversy will satisfy all four criteria. ${ }^{79}$ In terms of Collins and Evans's distinction between the technical and political phases of decision-making, Weinel's proposed criteria:

would only impact on the technical phase which deals with narrowly framed propositional questions - for example: Is AZT ... safe to be used for particular purposes in a public health sector? The political phase deals with the much wider question of preferences, for example: Do we want to spend taxpayer money on drug-based HIV/AIDS prevention programmes? ${ }^{80}$

Criticizing Thabo Mbecki's decision for using a counterfeit controversy (to influence a public policy decision) is legitimate, but if his decision was based on his aversion to dependency on foreign pharmaceutical companies, that would appropriately be open to political debate. Weinel concluded that recognition of a fake controversy is necessary for the appropriate political process to occur.

\section{Part V. Latour's Intervention: Down to Earth (2018)}

Echoing Durant and Weinel, Bruno Latour has highlighted the very same phenomena of (i) indifference to (or 'ignoring') experts' evidence of climate change, and (ii) the claim that a genuine controversy exists regarding climate science, notwithstanding substantial consensus. As to the first, Latour recently noted that Trump and his followers basically decided that, 'as to this less and less debatable truth about the New Climatic Regime, we are going to deny its very existence. ${ }^{81}$ And as to the second, over 15 years ago Latour identified such an 'artificially maintained scientific controversy' in a New York Times editorial:

Most scientists believe that [global] warming is caused largely by manmade pollutants that require strict regulation. Mr. Luntz [a Republican strategist] seems to acknowledge as much when he says that 'the scientific debate is closing against us.' His advice, however, is to emphasize that the evidence is not complete. ${ }^{82}$

Latour's diagnosis, therefore, parallels in some respects the focus on expertise in STS third-wave studies, and although theoretical differences remain, Collins and Latour seem to have reached a strikingly similar set of practical priorities.

\footnotetext{
72 Weinel, "Recognizing Counterfeit Scientific Controversies," 54.

${ }^{73}$ Weinel, "Recognizing Counterfeit Scientific Controversies," 55.

74 Weinel, "Recognizing Counterfeit Scientific Controversies," 56.

${ }^{75}$ Weinel, "Recognizing Counterfeit Scientific Controversies," 57.

${ }^{76}$ Weinel, "Recognizing Counterfeit Scientific Controversies," 58.

77 Weinel, "Recognizing Counterfeit Scientific Controversies," 61.

${ }^{78}$ Weinel, "Recognizing Counterfeit Scientific Controversies," 61.

${ }^{79}$ Weinel, "Recognizing Counterfeit Scientific Controversies," 56-57.

${ }^{80}$ Weinel, "Recognizing Counterfeit Scientific Controversies," 63-64.

${ }^{81}$ Latour, Down to Earth, 18.

${ }^{82}$ Latour, "Why Has Critique Run out of Steam?" 226-2227, 231, quoting “Environmental Word Games," Opinion.
} 


\section{Latour, Collins, and Science and Technology Studies}

By explaining the construction of scientific facts in terms of social causes or processes, [Latour suggested, the] social study of science ... had un-reflexively adopted a realist attitude for its own work. ... In heated exchanges in the 1990s ... with Collins and Yearley [among others], the gap between Latour and the social studies of science community widened. ${ }^{83}$

STS, like any discipline or sub-discipline, is not monolithic - it is riven with disagreements and debates. However, by the 1990 s, there seemed to be, at the very least, a unified effort 'to strip science of its extravagant claim to authority' ${ }^{84}$ by demonstrating that the scientific enterprise was not merely influenced by, but actually constituted by, social structuresscientific facts were to some degree socially constructed, not discovered. 'Constructivism,' therefore, stood in contrast to the 'realism' in conventional self-images of scientists. Consequently, Callon and Latour's charge that sociologists of science had become unwitting 'realists' was serious - they had, Latour observed, even as they were rejecting the realism that conceived of Nature as determinative of the results of scientific inquiry, merely exchanged that realism for a determinative 'social' realism. (Latour wanted to abandon the Nature/Society 'poles' in favor of a network of simultaneous human and non-human forcesNature and Society would not exist as independent factors but would only emerge visibly in that network.) Of course, in terms of name-calling, because Latour emphasized the role of material objects (as allies, in the network) in the construction of scientific facts, ${ }^{85}$ Latour was, in return, accused of being the old-fashioned, naïve realist. ${ }^{86}$

The significance of Latour and Woolgar's Laboratory Life: The Social Construction of Scientific Facts (1979) for the growth and initial unity of STS can hardly be exaggerated - it provided a model for ethnographic research as a method to reveal ofthidden social, rhetorical, and economic aspects of the scientific establishment. Likewise, one cannot exaggerate the significance of the revised sub-title of the second edition, The Construction of Scientific Facts. Gerald de Vries, noting Latour's unsettled place within STS, observed that omitting the term 'social' from the title reflected the fact that 'Latour was on a different trajectory than most of his colleagues in science studies. ${ }^{87}$ Even as Latour's work was, outside STS, considered post-modern and a threat to modern science, that work surprisingly 'incited ... severe opposition from his colleagues' ${ }^{88}$ in STS, especially from Harry Collins who, with Yearley, saw in Latour's writings an 'essentially conservative[,] prosaic view of science and technology. 89

In his first-hand account of the 1992 debate between Latour and Collins, de Vries credited Collins for providing 'the details' of what everyone knew - 'that science is a human affair and that reaching agreement plays a crucial role. ${ }^{90}$ Scientific methodology and observation on the part of scientists cannot fully explain scientific certainty. ${ }^{91}$ Scientific facts, in this approach:

are established only after closure of a discussion in a scientific community [and, therefore] depend on human institutions, beliefs and social processes. In other words, scientific facts are 'socially constructed.' 92

But had Collins erred in making science only a human affair? Latour agreed that if the scientist, the human, is ignored in our accounts of science, we might fall into a naïve realism; however, if the non-human is ignored, we:

fall back into the other pit, as bottomless as the first, of social constructivism, ignoring the role of nonhumans, on whom all of the people we study [i.e., scientists] are focusing their attention. ${ }^{93}$

\footnotetext{
${ }^{83}$ De Vries, Bruno Latour, 15.

${ }^{84}$ Callon, "Don't Throw the Baby Out," 346.

${ }^{85}$ See Garrety, "Actor Network Theory," 15.

${ }^{86}$ See Fuller, "Why science studies Has Never Been Critical," 8 (Latour "clearly re-opens the door to traditional ... explanations of science that incorporate both natural and social factors 'interacting' to produce . . . an experimental outcome").

${ }^{87}$ De Vries, Bruno Latour, 15.

${ }^{88}$ De Vries, Bruno Latour, 21.

${ }^{89}$ Collins, "Epistemological Chicken," 323.

${ }^{90}$ De Vries, Bruno Latour, 30.

${ }^{91}$ De Vries, Bruno Latour, 27.

${ }^{92}$ De Vries, Bruno Latour, 29-30.

${ }^{93}$ Latour, Pasteurization of France, 132.
} 
Scientific practice is understood by Latour as a co-production between human actors and non-human 'actants,' an intentional vocabulary choice in the effort to establish a new metalanguage. ${ }^{94}$ Importantly, Latour was not simply trying to emphasize Nature as well as Society, but was instead rejecting the Nature/Society dichotomy in favor of a 'generalized symmetry principle' (to replace the second-wave symmetry principle that truth and falsehood are both explained by Society, not Nature) - briefly, the social/human and the natural/non-human are treated symmetrically and only emerge when stabilized in quasi-objects in a network. ${ }^{95}$ An extended inquiry into Latour's approach is beyond the scope of this article, but a recent practical example is instructive:

\begin{abstract}
Latour was struck when he heard [a climatologist recently] defend his results not on the basis of the unimpeachable authority of science but by laying out ... 'the large number of researchers involved in climate analysis, the complex system for verifying data, the articles and reports, the principle of peer evaluation, the vast network of weather stations, floating weather buoys, satellites and computers that ensure the flow of information.' The climate denialists, by contrast, ... had none of this institutional architecture. Latour realized he was witnessing [a] shift: from scientists appealing to transcendent, capital-T Truth to touting the robust networks through which truth is, and has always been, established. ${ }^{96}$
\end{abstract}

Social forces and natural entities, that is, only appear later 'as a result of processes taking place in networks.' ${ }^{97}$

Finally, there is the wholesale critique of Latour by David Bloor in 1999, which included the argument that 'unresolved tensions ... are endemic' in the concept of co-production:

Latour never succeeds in giving a clear account of the process he calls the co-production of science and society. Indeed, such accounts as he does give are deeply obscure. ${ }^{98}$

By referring to social constructivism as a 'bottomless pit' (alongside the bottomless pit of naïve realism), ${ }^{99}$ Latour was also criticized for not understanding the so-called 'Strong Program' in STS (i.e., a 'program' critical of earlier, 'weak' versions of social constructivism) associated with David Bloor, Barry Barnes, and, in most accounts, Harry Collins; Bloor defended the Strong Program against Latour's:

idea that social factors are too impoverished to explain the rich detail of scientific work. ... Unfortunately he is working under the false assumption that, according to the Strong Program, a scientist is to be thought of as responding to society rather than to (non-social) nature.... Scientists are always responding to nature, but doing so collectively through their shared conventions and institutionalised concepts. ${ }^{100}$

There was never a need, Bloor concluded, to deny that observation 'plays a role in prompting and sustaining belief.' 101

The 1992 debate between Collins and Latour has far more features than those on which I have focused-there was a charge, likely exaggerated, by Latour that Collins's approach is an unacknowledged network theory ('not without resemblance to ours'), ${ }^{102}$ a dispute about whether inscriptions from instruments always require interpretation, ${ }^{103}$ and worries about Latour's

${ }^{94}$ See Callon, "Don't Throw the Baby Out," 353-354, for a discussion of Callon's efforts to create a new metalanguage. In response to Collins's criticism of that effort in "Epistemological Chicken," Callon responded:

All the shifts in vocabulary like "actant" instead of "actor," "actor network" instead of "social relations," "translation" instead of "interaction," "negotiation" instead of "discovery," "immutable mobiles" and "inscriptions" instead of "proof" and "data," "delegation" instead of "social roles," are derided because they are hybrid terms that blur the distinction between the really social and human-centered terms and the really natural and object-centered repertoires.

See Callon, "Don't Throw the Baby Out," 347.

${ }^{95}$ Latour, We Have Never Been Modern, 94-96.

${ }^{96}$ Kofman, "Bruno Latour, the Post-Truth Philosopher."

${ }^{97}$ Detel, "Social Constructivism":

Constructivism in the sense of the actor-network theory is social not in the strong sense that social forces that are presupposed to exist largely independently of scientific practices have a causal impact on these practices; but rather in the extremely weak sense that as a result of processes taking place in networks, a scientific claim can eventually be developed about a distinction between the natural and the social, and consequently also about the function of the social for scientific practices.

${ }^{98}$ Bloor, "Anti-Latour," 95, 98.

${ }^{99}$ Latour, Pasteurization of France, 132.

100 Bloor, "Anti-Latour," 90.

${ }^{101}$ Bloor, "Anti-Latour," 90.

${ }^{102}$ Callon, "Don't Throw the Baby Out," 362-64 (tracing Collins's use of the term "network" in Collins, but insisting that Collins does not have a genuine, compelling network theory).

${ }^{103}$ De Vries, Bruno Latour, 48-50. 
seeming anthropomorphism (e.g., the enthusiasm of Pasteur's microbes). ${ }^{104}$ However, I merely want to emphasize the manner in which both Latour and Collins, despite theoretical disagreements, find it pragmatically necessary in the contemporary political context to acknowledge the urgent need for reliable scientific expertise in government policies. In Latour's case, the role of the social is not jettisoned, but he emphasizes the need for robust climate science in the face of our current 'epistemological delirium.' ${ }^{105}$ In Collins' case, he insists that his third-wave theory is not a rejection of the second-wave emphasis on social structures, even as he embraces first-wave values for science. Both are critics of the post-truth era in politics, including the lack of confidence in scientific statements. And while some may say that Latour and Collins have abandoned STS's second-wave emphasis on social structures and become old-fashioned realists, Latour in his new book explains why (in his case) this is not true-and his explanation works for Collins as well: science needs trusted social institutions.

\section{Latour and the New Climatic Regime}

No attested knowledge can stand on its own, as we know very well. Facts remain robust only when they are supported by a common culture, by institutions that can be trusted, by a more or less decent public life, by more or less reliable media. ${ }^{106}$

In his list of social structures, Latour includes institutions alongside culture and the media. Collins and Evans, as well, emphasize the importance of trusted social institutions - science is a potential example and, as an institution, it has the capacity for moral leadership. ${ }^{107}$ In a pluralistic democracy, scientific expertise can be one of the checks and balances when an administration like Trump's ignores scientific evidence. ${ }^{108}$

Latour's Down to Earth: Politics in the New Climatic Regime was prompted not only by the election of President Trump, but also by the growth of three phenomena in advance of the election, namely (i) deregulation, (ii) human inequalities, and (iii) 'a systematic effort to deny the existence of climate change.' ${ }^{109}$ The latter phenomenon has resulted in the loss of a shared, common world-Trump withdrew not only from the Paris Climate Accord, but from the Earth, in order for the US to occupy another imagined earth and another imagined history in which 'modernization' continues. ${ }^{110}$ The actual Earth, however, will react to that 'action in such a way that [the US will] no longer have a stable and indifferent framework in which to lodge [its] desires for modernization.' 111

Latour's goal in the book is to provide a map of our new landscape - to orient the reader to the positions that have been imposed on us and redefined public life. ${ }^{112}$ There is some practical advice about how to act, politically, to resist the loss of a common world. ${ }^{113}$ For my purposes, I want to focus on what Latour calls the 'question of the sciences,' since science revealed the New Climatic Regime, and it is the target of climate change deniers. ${ }^{114}$ The 'deniers' include the people who are suspicious of elites, fearful, feeling betrayed, living 'within a fog of disinformation,' and, therefore, supporters of Trump; meanwhile, Latour observes, our 'rational' journalists not only identify these people as being naively attached to 'alternative facts,' but these journalists:

\footnotetext{
${ }^{104}$ De Vries, Bruno Latour, 71.

105 Latour, Down to Earth, 22.

${ }^{106}$ Latour, Down to Earth, 23. As an aside, the relation of "facts" to Nature is an important question in the history of STS; for a critique of Latour's unacknowledged belief in things-in-themselves, in his effort to "produce some manner of non-sociological, non-reductionist analysis of knowledge, one that neither reduces nature to society, nor society to nature," see Bloor, "Anti-Latour," 86-87. Conversely, Latour emphasizes the social support needed for "facts":

As the assaults on their expertise have increased, some scientists, Latour told me, have begun to realize that the classical view of science - the assumption that the facts speak for themselves and will therefore be interpreted by all citizens in the same way- "doesn't give them back their old authority."

Kofman, "Bruno Latour, the Post-Truth Philosopher."

${ }^{107}$ Collins, Why Democracies Need Science, 4-9.

${ }^{108}$ Collins, Experts and the Will of the People.

${ }^{109}$ Latour, Down to Earth, 1.

${ }^{110}$ Latour, Down to Earth, 2-5. Trump's withdrawal "was a declaration of war authorizing the occupation of all the other countries, if not with troops, at least with $\mathrm{CO}_{2}$, which America retains the right to emit." Latour, Down to Earth, 84 .

${ }^{111}$ Latour, Down to Earth, 84.

${ }^{112}$ Latour, Down to Earth, 2. Speaking of politics and the old labels (i.e., "markers" like Right, Left, Local, or Global) we use, Latour observes that everything "has to be mapped out anew." Latour, Down to Earth, 33.

There is simply no precedent for the current situation ... We understand nothing about the vacuity of contemporary politics if we do not appreciate the stunning extent to which the situation is unprecedented.

Latour, Down to Earth, 43, 44.

${ }^{113}$ Latour, Down to Earth, 94-99. "What to do? First of all, generate alternative descriptions ... We ought to give priority to resuming the work of description on the part of all animate beings." Latour, Down to Earth, 94, 98.

${ }^{114}$ Latour, Down to Earth, 65.
} 
continue to believe that facts stand up all by themselves, without a shared world, without institutions, without a public life, and that it would suffice to put the ignorant folk back in an old-style classroom . . . for reason to triumph at last. ${ }^{115}$

Journalists do not seem to realize that they 'live in an alternative world,' where there is climate change- 'there are now several worlds, ... and they are mutually incompatible.' ${ }^{116}$ And just as Collins and Evans prefer a world governed by consensus science (or at least scientific values - 'it is safer to rely on scientific values than scientific outcomes' ${ }^{\text {'17 }}$ ), Latour is clearly preferring, and advocating for, the world that honestly acknowledges climate change.

Latour is not only emphasizing the importance of social structures for the success of science, but he is also responding to the predictable criticism that the loss of confidence in science is due to the relativism and skepticism associated with the second wave of STS. ${ }^{118}$ Indeed, the debate between STS and those with traditional images of science appeared to be 'a prelude to the post-truth era,' culminating in the 'precipitous rise . . . in anti-scientific thinking,' the 'death of expertise,' and the election of a US 'president who invents the facts to suit his mood and goes after the credibility of anyone who contradicts him.' 119 STS scholar Steve Fuller even accepts responsibility for a post-truth world as the legacy of STS:

My own view has always been that a post-truth world is the inevitable outcome of greater epistemic democracy. In other words, once the instruments of knowledge production are made generally available — and they have been shown to work - they will end up working for anyone with access to them. ... We should finally embrace our responsibility for the post-truth world. ${ }^{120}$

Other STS scholars, like Sergio Sismondo, see Fuller as missing the point:

\begin{abstract}
Embracing epistemic democratization does not mean a wholesale cheapening of technoscientific knowledge. STS's detailed accounts of the construction of knowledge show that it requires infrastructure, effort, ingenuity and validation structures. Our arguments that 'it could be otherwise' ... point to other possible infrastructures, efforts, ingenuity and validation structures. That doesn't look at all like post-truth. ${ }^{121}$
\end{abstract}

And for Latour, the social constructivist critique always recognized the authority of science, a view 'shared because there was a common world':

Even this notion of a common world we didn't have to articulate, because it was obvious. . . Now we have people who no longer share the idea that there is a common world. And that of course changes everything. ${ }^{22}$

Scientists critical of STS may blame Latour due to his association with social constructivism (even though his own network theory is a challenge to many versions of social constructivism), which supposedly 'gave license to a pernicious anything-goes relativism that cynical conservatives were only too happy to appropriate for their own ends.' ${ }^{123}$ By contrast, given Latour's notion that the social and the natural, the human and the non-human, are 'stabilized' in the network:

${ }^{115}$ Latour, Down to Earth, 22, 25.

And people to whom it has never been announced openly (although they suspect it) that all the efforts to modernize for the last couple of centuries are at risk of collapsing, that all ideals of solidarity have been thrown overboard by their own leaders - these people are expected to have the confidence of a Louis Pasteur or a Marie Curie in scientific facts! Latour, Down to Earth, 23.

${ }^{116}$ Latour, Down to Earth, 25-26.

${ }^{117}$ Collins, Why Democracies Need Science, 23.

${ }^{118}$ See van Eeden, "Materializing Discourse Analysis."

To put it even more provocatively: would constructivists not have to allow Trump's infamous framing of global warming as a hoax of the Chinese as "one of the possible interpretations"? If so would social constructivism then not contribute to the disqualification of objective climatology, and endanger life on Earth by so doing? Indeed, was it not the constructivist movement that first pioneered the "post-fact" reality that we live in today?

Van Eeden, "Materializing Discourse Analysis."

119 Kofman, "Bruno Latour, the Post-Truth Philosopher."

${ }^{120}$ Fuller, "Embrace the Inner Fox." STS "recoiled from the post-truth worldview in 2004, when Bruno Latour famously waved the white flag in the Science Wars." Fuller, "Embrace the Inner Fox," citing Latour, "Why Has Critique Run out of Steam?"

${ }^{121}$ Sismondo, "Post-Truth?" 3.

${ }^{122}$ Kofman, "Bruno Latour, the Post-Truth Philosopher," quoting Latour (in an interview).

${ }^{123}$ Kofman, "Bruno Latour, the Post-Truth Philosopher": Latour himself has sometimes worried about the same thing. As early as 2004 he publicly expressed the fear that his critical "weapons," or at least a grotesque caricature of them, were being "smuggled" to the other side, as corporatefunded climate skeptics used arguments about the constructed nature of knowledge to sow doubt around the scientific consensus on climate change.

Kofman, "Bruno Latour, the Post-Truth Philosopher." 
our current post-truth moment is less a product of Latour's ideas than a validation of them. In the way that a person notices her body only once something goes wrong with it, we are becoming conscious of the role that Latourian networks play in producing and sustaining knowledge only now that those networks are under assault. ${ }^{124}$

Importantly, neither the climate change question nor the concern that STS contributed to the post-truth era are new for Latour. Responding to the 2003 New York Times editorial that quoted a Republican strategist who recommended emphasizing the 'lack of scientific certainty' in the face of scientific consensus on climate change, Latour wrote:

Do you see why I am worried? I myself have spent some time in the past trying to show 'the lack of scientific certainty' inherent in the construction of facts. ... But I did not exactly aim at fooling the public by obscuring the certainty of a closed argument. ... I'd like to believe that, on the contrary, I intended to emancipate the public from prematurely naturalized objectified facts. ... The question was never to get away from facts but closer to them, not fighting empiricism but, on the contrary, renewing empiricism. ${ }^{125}$

Finally, Latour's arguments in Down to Earth emphasize another co-production, in addition to the co-production of facts by nature and society - we are not simply living beings located in a stable atmosphere or environment, because that atmosphere is in part a result of our actions: 'in other words, there are not organisms on one side and an environment on the other, but a coproduction by both.' ${ }^{\text {, } 26}$

\section{Part VI. Conclusion}

Yes, the scientific facts are indeed constructed but they cannot be reduced to the social dimension because this dimension is populated by objects mobilized to construct it. ... The ozone hole is too social and too narrated to be truly natural; the strategy of industrial firms and heads of state is too full of chemical reactions to be reduced to power and interest; the discourse of the exosphere is too real and too social to boil down to meaning effects. Is it our fault if the networks are simultaneously real, like nature, narrated, like discourse, and collective, like society? ${ }^{127}$

There is always the danger of oversimplification when discussing a thinker like Latour, and while I remain critical of both (i) those scientists who reject Latour as the paradigmatic social constructivist ${ }^{128}$ and (ii) those, like Fuller, who accuse Latour of being a realist (complicit with the scientific establishment), ${ }^{129}$ I do recognize the paradoxical elements in Latour's substantial oeuvre. Latour's charge that Bloor was 'explaining nature by society' was, in Bloor's view, a misunderstanding of the first symmetry principle; thus, raising questions about the value of the new, generalized symmetry principle. ${ }^{130}$

That internal STS debate, however, eclipses another troubling aspect of Latour's terminology in the Trump era-if the 'ozone hole is too social and too narrated to be truly natural,' then perhaps citizens need not worry as much about the effects of pollution! STS, it seems, can easily be weaponized by the populist right wing in US politics. However, this is not the time, in the sphere of public policy, to try to explain or debate the intricacies of STS with respect to the roles (identified by Latour) of society, language, and nature in the science. STS purity, in whatever form (social constructivism? Strong Program? Actor network theory?), is important to some but irrelevant in the face of those who view scientific consensus as a deep state conspiracy.

My point in this article has not been to adequately summarize all of Collins' writings, or to defend the Latourian view of nature, language, and culture, but rather to show how Latour and Collins, sparring partners in the 1990s, have arrived at a similar place with respect to the role of scientific expertise in policy contexts, including the importance of science as a trusted institution.

\footnotetext{
${ }^{124}$ Kofman, "Bruno Latour, the Post-Truth Philosopher": "Latour believes that if the climate skeptics and other junk scientists have made anything clear, it's that the traditional image of facts was never sustainable to begin with."

${ }^{125}$ Latour, "Why Has Critique Run out of Steam?" 226-227, 231, quoting “Environmental Word Games,” Opinion.

${ }^{126}$ Latour, Down to Earth, 76.

${ }^{127}$ Latour, We Have Never Been Modern, 6.

${ }^{128}$ Latour remarked that after a dozen books detailing the "complete implausibility" of socially accounting for scientific objects, scientists nevertheless reacted with skepticism:

You can dust your hands with flour as much as you wish, [but] the black fur of the critical wolf will always betray you; your deconstructive teeth have been sharpened on too many of our innocent labs - I mean lambs! - for us to believe you.

Latour, "Why Has Critique Run out of Steam?" 232.

${ }^{129}$ See Fuller, "Why Science Studies Has Never Been Critical," 6. Fuller blames the "Parisians" (Latour and Callon) and their actor network theory for the decline of STS - he identifies both an "aversion to normative judgment" and "open antagonism to the adoption of "critical' perspectives."

${ }^{130}$ Bloor, "Anti-Latour," 90.
} 
There remains an internal debate over whether scientists should be activists; Collins and Evans have concerns with Heather Douglas's conception of politically activist scientists, ${ }^{131}$ while Latour seems to encourage activism on the part of scientists. ${ }^{132}$ However, there are important parallels between Collins's early notion that closure of a scientific controversy is 'brought about by judging the competence of the experimenter' in the scientific community ('including considerations about the degree to which the experimenter is conceived as properly socialized' into that community), ${ }^{133}$ and Latour's broader view that in the current era of alternative facts:

\begin{abstract}
it has become clear that whether or not a statement is believed depends far less on its veracity than on the conditions of its 'construction' - that is, who is making it, to whom it's being addressed and from which institutions it emerges and is made visible. A greater understanding of the circumstances out of which misinformation arises and the communities in which it takes root, Latour contends, will better equip us to combat it. ${ }^{134}$
\end{abstract}

At this juncture, we should be paying more attention to institutions - both the ones that spread misinformation (including the Trump administration) and the ones providing consensus expertise concerning the natural world-in our assessments of how science is perceived. Even as we recognize, for example, the variable experimental conventions underlying, or the rhetorical and economic underpinnings, of scientific expertise, we should not raise doubts about the value of expertise-we should not add to the distrust of scientific institutions at this time. That goal is the commonality between Collins (with Evans) and Latour, and it offers to STS scholars a framework for critique of Trump and a 'constructive' role in policy contexts nowadays.

\title{
Primary Sources
}

Union of Concerned Scientists (Center for Science and Democracy). Sidelining Science Since Day One: How the Trump Administration Has Harmed Public Health and Safety in its First Six Months. July 13, 2017.

https://www.ucsusa.org/center-science-and-democracy/promoting-scientific-integrity/sidelining-science-from-day-one.

Van Hollen, Chris. "Van Hollen, Senators Call on Trump to Abandon Plan to Form Anti-Science Panel that would Threaten National Security, Ignore Climate Change Facts.” Washington DC. February 28, 2019.

https://www.vanhollen.senate.gov/news/press-releases/van-hollen-senators-call-on-trump-to-abandon-plan-to-form-antiscience-panel-that-would-threaten-national-security-ignore-climate-change-facts.

\section{Bibliography}

Alba, Davey and Sheera Frenkel. "Medical Expert Who Corrects Trump Is Now a Target of the Far Right." New York Times, March 29, 2020. https://www.nytimes.com/2020/03/28/technology/coronavirus-fauci-trump-conspiracy-target.html Andrews, Robin. "Here's a List of All the Science That Donald Trump Denies: Second Edition.” IFLSCIENCE! April 27, 2018.https://www.iflscience.com/policy/heres-list-all-science-donald-trump-denies-second-edition/all/

Bloor, David. “Anti-Latour.” Studies in the History and Philosophy of Science 30, no 1 (1999): 81-112.

Callon, Michel and Bruno Latour. "Don't Throw the Baby Out with the Bath School." In Science as Practice and Culture, edited by Andrew Pickering, 343-368. Chicago: University of Chicago Press, 1992.

Collier, Roger. "Massive Cuts to Science and Medicine in Trump Budget." Canadian Medical Association Journal 189, no 23 (June 12, 2017): E812-E813. https://dx.doi.org/10.1503\%2Fcmaj.1095437

${ }^{131}$ Collins, Why Democracies Need Science, 119-28.

Of course, no one can be against the softening of boundaries between the scientific profession and society as a whole .

. but one cannot expect every scientist ... whose work has social implications to consult citizens and stakeholders about the appropriate balance of risks and benefits before submitting a paper. This is not what scientists do.

Collins, Why Democracies Need Science, 124.

132 The traditional conception of nature cannot be politicized, Latour observes, since it was "invented precisely to limit human action thanks to an appeal to the laws of objective nature that cannot be questioned." Latour, Down to Earth, 65.

Climatologists, [Latour] says, must recognize that, as nature's designated representatives, they have always been political actors, and that they are now combatants in a war whose outcome will have planetary ramifications. We would be in a much better situation, he has told scientists, if they stopped pretending that "the others"- the climate-change deniers - "are the ones engaged in politics and that you are engaged "only in science."

Kofman, "Bruno Latour, the Post-Truth Philosopher" (interview of Latour).

${ }^{133}$ De Vries, Bruno Latour, 30.

${ }^{134}$ Kofman, "Bruno Latour, the Post-Truth Philosopher." 
Collins, Harry. Changing Order. Chicago: University of Chicago Press, 1985.

Collins, Harry and Robert Evans. Why Democracies Need Science. Cambridge: Polity Press, 2017.

Collins, Harry and Robert Evans. "The Third Wave in Science Studies: Studies in Expertise and Experience." Social Studies of Science 32, no 2 (2002): 235-296. https://doi.org/10.1177\%2F0306312702032002003

Collins, Harry and Steven Yearley. "Epistemological Chicken.” In Science as Practice and Culture, edited by Andrew Pickering, 301-326. Chicago: University of Chicago Press, 1992.

Collins, Harry, Robert Evans, Darrin Durant and Martin Weinel. Experts and the Will of the People: Society, Populism and Science. New York: Palgrave Pivot, 2020.

Durant, Darrin. "Ignoring Experts." In The Third Wave in Science and Technology Studies: Future Research Directions on Expertise and Experience, edited by David Caudill, Shannon Conley, Michael Gorman and Martin Weinel, 33-52. New York: Palgrave Macmillan, 2019.

De Vries, Gerald. Bruno Latour. Cambridge: Polity Press, 2016.

Detel, Wolfgang. "Social Constructivism." In International Encyclopedia of the Social \& Behavioral Sciences, edited by Neil J. Smelser and Paul B. Baltes. Amsterdam: Elsevier Ltd., 2001.

Eilperin, Juliet, Josh Dawsey and Brady Dennis. "White House Blocked Intelligence Aide's Written Testimony Saying Human-Caused Climate Change Could Be 'Possibly Catastrophic.”' Washington Post. June 8, 2019.

https://www.msn.com/en-us/news/politics/white-house-blocked-intelligence-aides-written-testimony-saying-humancaused-climate-change-could-be-possibly-catastrophic/ar-AACysAa?li=BBnb7Kz

Farber, Dan. "Trump on the Environment: A Study in Falsehood.” Legal Planet (Berkeley Law/UCLA Law). March 28, 2019. https://legal-planet.org/2019/03/28/trump-on-the-environment-a-study-in-false-witness/

Fuller, Steve. "Embrace the Inner Fox: Post-Truth as the STS Symmetry Principle Universalized." Social Epistemology Review and Reply Collective. December 25, 2016. https://social-epistemology.com/2016/12/25/embrace-the-inner-foxpost-truth-as-the-sts-symmetry-principle-universalized-steve-fuller/

Fuller, Steve. "Why Science Studies Has Never Been Critical of Science: Some Recent Lessons on How to Be a Helpful Nuisance and a Harmless Radical." Philosophy of the Social Sciences 30 (1999): 5-32. https://doi.org/10.1177\%2F004839310003000101

Garrety, Karin. "Actor Network Theory." In Being Practical with Theory: A Window into Business Research, edited by H. Hasan, 15-19. Morrisville, North Carolina: Lulu Press, 2014.

Gopnik, Adam. "Younger Longer." New Yorker. May 20, 2019. https://www.newyorker.com/magazine/2019/05/20/can-welive-longer-but-stay-younger?verso=true

Grens, Kerry. "NIH Scientists Banned from Studying Human Fetal Tissue," The Scientist. June 6, 2019. https://www.thescientist.com/news-opinion/nih-scientists-banned-from-studying-human-fetal-tissue-65977.

Holmes, Jack. “There Aren’t Two Sides to Science, That's Just Your Coal Money Talking.” Esquire. December 6, 2016. http://www.espquire.com/news-politics/a25422366/trump-ambassador-to-canada-climate-change-scientists/

Hutchens, Gareth. "Turnbull Ignored Advice That Renewable Energy Not to Blame for SA Blackouts." The Guardian. February 13, 2017. https://www.theguardian.com/australia-news/2017/feb/13/turnbull-ignored-advice-that-renewableenergy-not-to-blame-for-sa-blackouts

Jasanoff, Sheila. "The Practices of Objectivity in Regulatory Science." In Social Knowledge in the Making, edited by C. Camic, N. Gross and M. Lamont, 307-337. Chicago: University of Chicago Press, 2011.

Kofman, Ava. "Bruno Latour, the Post-Truth Philosopher, Mounts a Defense of Science." New York Times Magazine. October 25, 2018. https://www.nytimes.com/2018/10/25/magazine/bruno-latour-post-truth-philosopher-science.html

Latour, Bruno. Down to Earth: Politics in the New Climatic Regime. Translated by Catherine Porter. Cambridge: Polity Press, 2018.

Latour, Bruno. "Why Has Critique Run out of Steam? From Matters of Fact to Matters of Concern." Critical Inquiry 30 (Winter 2004): 225-248. https://doi.org/10.1086/421123

Latour, Bruno. We Have Never Been Modern. Translated by Catherine Porter. Cambridge: Harvard University Press, 1993.

Latour, Bruno. The Pasteurization of France. Translated by Alan Sheridan and John Law. Cambridge: Harvard University Press, 1988.

Lewis, Michael. The Fifth Risk. New York: W. W. Norton, 2018.

Lewis, Tanya. "A Year of Trump: Science Is a Major Casualty in the New Politics of Disruption." Scientific American. December 14, 2017. https://www.scientificamerican.com/article/a-year-of-trump-science-is-a-major-casualty-in-the-newpolitics-of-disruption/

Limbaugh, Rush. "Peer Review Science Exposed as Fraud.” August 28, 2015 https://www.rushlimbaugh.com/daily/2015/08/28/peer_review_science_exposed_as_fraud/.

Lynch, Michael. "Expertise, Skepticism and Cynicism: Lessons from Science \& Technology Studies." Spontaneous Generations 1, no 1 (2007): 17-24.

Mervis, Jeffrey. “Trump’s 2018 Budget Proposal ‘Devalues' Science.” Science 355 no 6331 (March 24, 2017): 1246. https://science.sciencemag.org/content/355/6331/1246.long. 
New York Times. "Environmental Word Games.” Opinion. March 15, 2003.

Pierce, Charles. "The Trump Administration Will Stop at Nothing to Suppress Real Climate Science: Policy Led by Jealousy and Grudge-Holding Is an Existential Threat to Life on This Planet." Esquire. May 28, 2019. https://www.esquire.com/news-politics/politics/a27608847/trump-administration-climate-science-suppression/.

Scientific American. “Trump's Views on Science Are Shockingly Ignorant.” Editorial. November 1, 2016. https://www.scientificamerican.com/article/trump-comments-on-science-are-shockingly-ignorant/

Shapin, Steven. “Is There a Crisis of Truth?” Los Angeles Review of Books. December 2, 2019. https://lareviewofbooks.org/article/is-there-a-crisis-of-truth/.

Sharfstein, Joshua. "Science and the Trump Administration." The JAMA Forum. October 10, 2017. https://jamanetwork.com/journals/jama/fullarticle/2656798.

Sismondo, Sergio. "Post-Truth?” Social Studies of Science 47, no 1 (2017): 3-6 https://doi.org/10.1177\%2F0306312717692076

Van Eeden, Pepijn. "Materializing Discourse Analysis with James, Schmitt and Latour.” Palgrave Communications 3 (2012): 17039. https://www.nature.com/articles/palcomms201739.

Weinel, Martin. "Recognizing Counterfeit Scientific Controversies in Science Policy Contexts: A Criteria-Based Approach." In The Third Wave in Science and Technology Studies: Future Research Directions on Expertise and Experience, edited by David Caudill, Shannon Conley, Michael Gorman and Martin Weinel, 53-70. New York: Palgrave Macmillan, 2019.

Wynne, Brian. "Elephants in the Rooms Where Publics Encounter 'Science'?: A Response to Darrin Durant, 'Accounting for Expertise: Wynne and the Autonomy of the Lay Public.'” Public Understanding of Science 17, no 1 (2008): 21-33. https://doi.org/10.1177\%2F0963662507085162 